"use its scale and procurement power to" meet sustainability goals, including "100 percent carbon pollution-free electricity" by 2030 and "100 percent zero-emission vehicle acquisitions by 2035."76

\title{
InTERnATIONAL Human Rights and Humanitarian Law
}

United States Indicts Iranian and Chinese Government Agents for Targeting Individuals in the United States

doi:10.1017/ajil.2021.73

In July 2021, the U.S. Department of Justice announced two indictments charging Iranian and Chinese government officials and others acting at their behest with a variety of crimes stemming from two separate plots to coerce U.S. residents to return to those countries. The first involved four Iranians and a U.S. resident who took steps to kidnap a U.S. citizen of Iranian origin and transport her to Iran to answer for regime criticism. The second charged nine individuals, including a Chinese prosecutor and a policeman, with crimes relating to an operation to surveil, harass, and threaten U.S. residents with the aim of compelling their return to China. U.S officials denounced the operations as contrary to human rights and the rule of law.

The U.S. indictments follow several recent high-profile examples of authoritarian states targeting dissidents abroad in operations that have drawn international condemnation. For example, on February 13, 2017, two unwitting assassins directed by North Korean agents doused Kim Jong-nam, the "estranged elder brother" of North Korean leader Kim Jong-un, with a VX nerve agent in the Kuala Lumpur International Airport, leading to his death. ${ }^{1}$ The incident damaged relations between North Korea and Malaysia and prompted the United States to sanction North Korea. ${ }^{2}$ In another case, on March 4, 2018, two members of Russia's G.R.U. military intelligence agency applied the Novichok nerve agent to the doorknob of former Russian spy and corruption whistleblower Sergei Skripal in Salisbury, England resulting in the near fatal poisoning of him and others, as well as at least one

${ }^{76}$ Exec. Order 14,057, 86 Fed. Reg. 70,935, 70,935 (Dec. 13, 2021); see also White House, Federal Sustainability Plan: Catalyzing America's Clean Energy Industries and Jobs (Dec. 2021), available at https://www.sustainability.gov/pdfs/federal-sustainability-plan.pdf [https://perma.cc/T2H8-2HVN].

${ }^{1}$ Richard C. Paddock \& Choe Sang-Hun, Kim Jong-nam's Death: A Geopolitical Whodunit, N.Y. Times (Feb. 22, 2017), at https://www.nytimes.com/2017/02/22/world/asia/kim-jong-nam-assassination-korea-malaysia. html; Richard C. Paddock, Woman Convicted in Kim Jong-nam's Killing Is Freed in Malaysia, N.Y. Times (May 2, 2019), at https://www.nytimes.com/2019/05/02/world/asia/kim-jong-nam-assassination-vietnam.html.

${ }^{2}$ Rozanna Latiff \& A. Ananthalakshmi, Malaysia Further Downgrading Ties with North Korea a Year After Airport Assassination: Sources, ReuTERs (Feb. 13, 2018), at https://www.reuters.com/article/us-northkorea-malaysia-kim/malaysia-further-downgrading-ties-with-north-korea-a-year-after-airport-assassination-sourcesidUSKBN1FX1GB; Reuters, U.S. Sanctions North Korea over VX Assassination of Kim Jong Nam, NBC NEws (Mar. 7, 2018), at https://www.nbcnews.com/news/north-korea/u-s-sanctions-north-korea-over-vx-assassination-kim-jong-n854366. 
death. ${ }^{3}$ In response, the United Kingdom, United States, and other allies expelled Russian diplomats, and the United States sanctioned Russia. ${ }^{4}$ Also in 2018, Saudi Arabian agents killed U.S.-based Saudi dissident journalist Jamal Khashoggi in the Saudi consulate in Istanbul, Turkey in an operation that U.S. intelligence agencies have publicly confirmed was ordered by Saudi Crown Prince Mohammed bin Salman. ${ }^{5}$ In February 2021, the Biden administration announced "Khashoggi Ban" visa sanctions on seventy-six Saudis "believed to have been engaged in threatening dissidents overseas, including but not limited to the Khashoggi killing," adding to sanctions imposed in 2018 on direct participants in the killing. ${ }^{6}$ More recently, on May 23, 2021, Belarusian authorities forced a Ryanair flight from Greece to Lithuania to land in Minsk in order to arrest exiled Belarusian dissident Roman Protasevich, who was a passenger on the plane. ${ }^{7}$ The interference with international aviation prompted widespread international condemnation and sanctions against the Belarusian regime. ${ }^{8}$

On July 13, 2021, the U.S. District Court for the Southern District of New York unsealed an indictment against an Iranian intelligence officer, Alireza Shavaroghi Farahani, three intelligence assets working for him, and a U.S. resident of Iranian origin for a plot to kidnap Iranian-American journalist and human rights activist Masih Alinejad from Brooklyn to silence her criticisms of the Iranian regime. ' The indictment refers to Alinejad as "Victim-1," but she subsequently identified herself as the target of the plot. ${ }^{10}$ According to the Justice Department, the scheme followed a failed 2018 attempt by Iranian officials to "induce relatives of [Alinejad], who reside in Iran, to invite [her] to travel to a third country, apparently for the purpose of having [her] arrested or detained and transported to Iran for imprisonment." 11 The indictment alleges that the defendants used laundered money to acquire private investigation surveillance services under false pretenses, using the surveillance to track Alinejad's residence and associates. ${ }^{12}$ The defendants also researched ways to

\footnotetext{
${ }^{3}$ Michael Schwirtz \& Cora Engelbrecht, U.K. Police Charge 3rd Man in Effort to Kill Russian Dissident, N.Y. Times (Sept. 21, 2021), at https://www.nytimes.com/2021/09/21/world/europe/skripal-arrest.html.

${ }^{4}$ Katie Rogers \& Eileen Sullivan, Trump and Western Allies Expel Scores of Russians in Sweeping Rebuke Over U.K. Poisoning, N.Y. Times (Mar. 26. 2018), at https://www.nytimes.com/2018/03/26/world/europe/trump-russia-diplomats-expulsion.html; Michael Crowley \& Julian E. Barnes, Trump Adds to Sanctions on Russia Over Skripals, N.Y. Times (Aug. 1, 2019), at https:/www.nytimes.com/2019/08/01/us/politics/russia-sanctions-executive-order.html.

${ }^{5}$ See Kristen E. Eichensehr, Contemporary Practice of the United States, 115 AJIL 545, $545-48$ (2021).

${ }^{6}$ U.S. Dep't of State Press Release, Accountability for the Murder of Jamal Khashoggi (Feb. 26, 2021), at https://www.state.gov/accountability-for-the-murder-of-jamal-khashoggi [https://perma.cc/6T8V-ZTET]; Eichensehr, supra note 5, at 546.

${ }^{7}$ Kristen E. Eichensehr, Contemporary Practice of the United States, 115 AJIL 722, 724 (2021); Belarus Plane: What We Know and What We Don't, BBC (June 25, 2021), at https://www.bbc.com/news/world-europe57239521.

${ }^{8}$ Eichensehr, supra note 7 , at 724-28.

${ }^{9}$ U.S. Dep't of Justice Press Release, Iranian Intelligence Officials Indicted on Kidnapping Conspiracy Charges (July 13, 2021), at https://www.justice.gov/opa/pr/iranian-intelligence-officials-indicted-kidnapping-conspiracycharges [https://perma.cc/L4NE-W4UH]; Indictment, United States v. Farahani et al., Cr. No. 21-430 (S-1) (RA) (S.D.N.Y. July 13, 2021), at https://www.justice.gov/opa/press-release/file/1411371/download [https:// perma.cc/6C3T-AMRM]; Rachel Pannett, Iranian Intelligence Agents Plotted Brazen Abduction of Brooklyn Dissident Journalist, U.S. Prosecutors Say, Wash. PosT (July 14, 2021), at https:/www.washingtonpost.com/ world/2021/07/14/iran-journalist-kidnapping-alinejad.

${ }^{10}$ Indictment, supra note 9, at 2; Pannett, supra note 9.

${ }^{11}$ Indictment, supra note 9 , at 2 .

${ }^{12}$ U.S. Dep't of Justice, supra note 9; Indictment, supra note 9, at 3.
} 
transport Alinejad out of the United States, including using "military-style speedboats," and "maritime travel from New York to Venezuela, . . . whose de facto government has friendly relations with the regime in Iran." 13 The indictment charged Farahani and the three intelligence assets with conspiracy to kidnap, as well as conspiracy to violate other laws including sanctions on Iran, bank and wire fraud, and money laundering. ${ }^{14}$ The U.S. resident, the only defendant brought into custody, is accused of providing financial services to support the plot rather than directly participating in the kidnapping scheme. ${ }^{15}$

In announcing the indictment, the U.S. attorney for the Southern District of New York asserted that "'[a]mong this country's most cherished freedoms is the right to speak one's mind without fear of government reprisal," and that "[a] U.S. citizen living in the United States must be able to advocate for human rights without being targeted by foreign intelligence operatives." 16 The Justice Department warned that " $[\mathrm{t}]$ he network that Farahani directs has also targeted victims in other countries, including. . . Canada, the United Kingdom and the United Arab Emirates."17

When asked about the indictment, White House Press Secretary Jen Psaki stated that "we categorically condemn Iran's dangerous and despicable reported plot to kidnap a U.S. citizen on U.S. soil," and declared Iran's "attempt to silence the voices of those peacefully working to address the situation, both inside of Iran and outside of Iran" to be "appalling." 18 In speaking to the press, the target of the plot, Masih Alinejad, said, "I knew that this is the nature of the Islamic Republic, you know, kidnapping people, arresting people, torturing people, killing people. But I couldn't believe it that this is going to happen to me in [the] United States of America." 19 After a phone call with Alinejad, Secretary of State Antony Blinken tweeted that she "has demonstrated tremendous courage," and he "affirmed that the U.S. will always support the indispensable work of independent journalists around the world" and "won't tolerate efforts to intimidate them or silence their voices." 20 The Committee to Protect Journalists denounced the kidnapping plot and said that "'U.S. authorities must ensure that the perpetrators of this scheme are held to account, and Iran must cease

${ }^{13}$ Indictment, supra note 9, at 4.

${ }^{14} \mathrm{Id}$. at $10-33$.

${ }^{15}$ See U.S. Dep't of Justice, supra note 9; Indictment, supra note 9, at 8-9, 29-34; U.S. Dep't of Justice Press Release, Manhattan U.S. Attorney Announces Kidnapping Conspiracy Charges Against an Iranian Intelligence Officer and Members of an Iranian Intelligence Network (July 13, 2021), at https://www.justice.gov/usaosdny/pr/manhattan-us-attorney-announces-kidnapping-conspiracy-charges-against-iranian [https://perma.cc/ YLX9-W4BT].

${ }^{16}$ U.S. Dep't of Justice, supra note 9 (quoting U.S. Attorney for the Southern District of New York Audrey Strauss).

${ }^{17} I d$.

${ }^{18}$ White House Press Release, Press Briefing by Press Secretary Jen Psaki (July 14, 2021), at https://www.whitehouse.gov/briefing-room/press-briefings/2021/07/14/press-briefing-by-press-secretary-jen-psaki-july-14-2021 [https://perma.cc/SGX7-SWM5].

${ }^{19}$ Deepti Hajela \& Larry Neumeister, Iran Foreign Ministry: Iran Kidnap Plot Is "Imaginary Story," Assoc. Press (July 14, 2021), at https://apnews.com/article/middle-east-government-and-politics-iran3f57753819d62f85b0e6ad32750d2f61 (quoting Alinejad).

${ }^{20}$ Antony Blinken (@SecBlinken), TwitTer (July 19, 2021, 8:08 p.m.), at https://twitter.com/SecBlinken/ status/1417275150463033346?s=20 [https://perma.cc/5XAE-PE4X]; see also Blinken Speaks with Iranian American Journalist Targeted in Kidnap Plot, VOA News (July 20, 2021), at https://www.voanews.com/a/middleeast_voa-news-iran_blinken-speaks-iranian-american-journalist-targeted-kidnap-plot/6208458.html. 
its efforts to harass and harm journalists globally." 21 In September, the United States followed up on the incident by imposing sanctions on the indicted Iranian intelligence official and operatives. ${ }^{22}$

For its part, Iran has denied the allegations. Iranian Foreign Ministry spokesperson Saeed Khatibzadeh characterized "the plot as 'Hollywood-style scenarios' and 'baseless and ridiculous' accusations unworthy of a response." 23 He further stated, “'[m]aking such an imaginary story is not unlikely by the U.S. Its entire short history is full of assassination, kidnapping and sabotage in other countries."' 24

In a second case, a federal grand jury in the Eastern District of New York issued a superseding indictment on July 21, 2021, charging nine individuals with crimes related to their participation in a People's Republic of China (PRC) government "campaign to harass, stalk, and coerce certain residents of the United States to return to [China] as part of a global, concerted, and extralegal repatriation effort known as 'Operation Fox Hunt.'"25 The indictment alleges that "Operation Fox Hunt was a PRC Ministry of Public Security initiative to locate and repatriate alleged Chinese 'fugitives' who had fled to foreign countries, including the United States," but to do so without properly coordinating with the United States. ${ }^{26}$ Instead, the indictment explains, "PRC government officials . . . traveled to the United States and directed non-official operatives . . to, among other things, surveil and harass their intended targets," including "threaten[ing] the targets and their families with harm to coerce the targets to return to the PRC."27

The indictment alleges that China previously obtained International Criminal Police Organization (Interpol) "red notices" for the targets in this case, alleging that they were wanted in China for, among other things, embezzlement and accepting bribes. ${ }^{28}$ From 2016 to 2019, PRC government officials, including a police officer with the Wuhan Public Security Bureau and a prosecutor with the Hanyang People's Protectorate, traveled to the United States to direct efforts to coerce the targets into returning to China. ${ }^{29}$ In 2017 , for example, the defendants allegedly brought the elderly father of one of the targets

${ }^{21}$ Comm. to Protect Journalists, US Indicts 5 Iranian Nationals Over Attempted Kidnapping of US-based Journalist Masih Alinejad (July 14, 2021), at https://cpj.org/2021/07/us-indicts-5-iranian-nationals-overattempted-kidnapping-of-us-based-journalist-masih-alinejad (quoting the Committee's Middle East and North Africa Program Coordinator Sherif Mansour).

${ }^{22}$ U.S. Dep't of the Treasury Press Release, Treasury Sanctions Iranian Intelligence Network Targeting Iranian-American Activist in the United States (Sept. 3, 2021), at https://home.treasury.gov/news/pressreleases/jy0343.

${ }^{23}$ Hajela \& Neumeister, supra note 19.

${ }^{24}$ Id. (quoting Iranian Foreign Ministry Spokesperson Saeed Khatibzadeh).

${ }^{25}$ U.S. Dep't of Justice Press Release, Nine Individuals Charged in Superseding Indictment with Conspiring to Act as Illegal Agents of the People's Republic of China (July 22, 2021), at https://www.justice.gov/opa/pr/nineindividuals-charged-superseding-indictment-conspiring-act-illegal-agents-people-s [https://perma.cc/WF3N9YFS]; Indictment, United States v. Ji et al., Cr. No. 21-CR-265 (S-1) (PKC) (E.D.N.Y. July 21, 2021), at https://www.justice.gov/opa/press-release/file/1414496/download [https://perma.cc/4L24-V25A].

26 Indictment, supra note 25 , at 3.

${ }^{27}$ Id. at 3-4; see also Sebastian Rotella \& Kirsten Berg, Operation Fox Hunt: How China Exports Repression Using a Network of Spies Hidden in Plain Sight, ProPublica (July 22, 2021), at https://www.propublica.org/article/operationfox-hunt-how-china-exports-repression-using-a-network-of-spies-hidden-in-plain-sight (detailing Operation Fox Hunt activities in the United States).

${ }^{28}$ Indictment, supra note 25 , at 4 .

29 Id. at $1-2,4$. 
from China to the United States to deliver a threat that if the target did not return to China, his family there would be harmed. ${ }^{30}$

When some of the defendants were initially charged in October 2020, Assistant Attorney General John C. Demers condemned the operation, noting that " $[\mathrm{t}]$ here are many established ways that rule of law abiding nations conduct international law enforcement activity. This certainly isn't one of them." ${ }^{31} \mathrm{He}$ further explained that some of China's targets

may well be wanted on traditional criminal charges and they may even be guilty of what they are charged with. But in many instances the hunted are opponents of Communist Party Chairman Xi-political rivals, dissidents, and critics. And in either event, the operation is a clear violation of the rule of law and international norms. ${ }^{32}$

In announcing the superseding indictment, which added as a defendant the prosecutor with the Hanyang People's Protectorate, U.S. officials denounced China's actions as "'undemocratic, authoritarian, and contrary to the rule of law," and noted that the fact that "'a prosecutor and police officer not only directed and participated in a criminal scheme on U.S. soil, but then attempted to cover it up, is an affront to justice of the highest order."'33

When asked about the superseding indictment, China's Foreign Ministry Spokesperson Zhao Lijian stated that China follows international law and accused the United States of "smear[ing] Chinese efforts to repatriate corrupt fugitives and recover illegal proceeds." 34 He further asserted:

The US has the largest number of Chinese fugitives suspected of corruption and economic crime. In recent years, the US has been inactive in responding to China's requests for cooperation on repatriating fugitives. This is against the spirit of the UN Convention Against Transnational Organized Crime and the UN Convention against Corruption. We urge the US to correct its mistakes, actively facilitate China's efforts to repatriate corrupt fugitives and recover illegal proceeds, faithfully fulfill its obligations and commitments, and avoid degenerating into a safe haven for criminals. ${ }^{35}$

In both cases, U.S. law enforcement officials arrested defendants located in the United States, but the foreign government officials and other defendants located in China and Iran remain at large. ${ }^{36}$

${ }^{30} I d$. at 5-9.

31 U.S. Dep't of Justice Press Release, Assistant Attorney General John C. Demers Delivers Remarks Announcing People's Republic of China Related Arrests (Oct. 28, 2020), at https://www.justice.gov/opa/ speech/assistant-attorney-general-john-c-demers-delivers-remarks-announcing-peoples-republic [https://perma. cc/QAM8-ECEJ]

${ }^{32} I$. .

${ }^{33}$ U.S. Dep't of Justice, supra note 25 (quoting FBI Assistant Director Alan E. Kohler and Acting Attorney General for the National Security Division Mark Lesko, respectively).

${ }^{34}$ Ministry of Foreign Affairs of the People's Republic of China Press Release, Foreign Ministry Spokesperson Zhao Lijian's Regular Press Conference (July 23, 2021), at https:/www.fmprc.gov.cn/mfa_eng/xwfw_665399/ s2510_665401/2511_665403/202107/t20210723_9170792.html.

35 Id.

${ }^{36}$ U.S. Dep't of Justice, supra note 15; U.S. Dep't of Justice Press Release, Eight Individuals Charged With Conspiring to Act as Illegal Agents of the People's Republic of China (Oct. 28, 2020), at https://www.justice.gov/ 
Given the nature of the charges and the absence of U.S. extradition treaties with Iran and China, cooperation from their national governments to facilitate prosecution is unlikely. ${ }^{37}$

INTERNATIONAL CRIMINAL LAW

Huawei's Meng Wanzhou Released to China After Entering into Deferred Prosecution Agreement with U.S. Justice Department

doi:10.1017/ajil.2021.72

On September 24, 2021, Canadian authorities released Meng Wanzhou, Chief Financial Officer of Huawei Technologies and daughter of its founder, to China after she entered a Deferred Prosecution Agreement (DPA) with the U.S. Justice Department (DOJ) on charges of violating U.S. sanctions on Iran. At the request of the United States, Canadian authorities arrested Meng in December 2018 and subsequently held her under house arrest in Vancouver. Meng fought extradition to the United States, ${ }^{1}$ and the case became a major source of friction between China, the United States, and Canada. Shortly after Meng's detention, China arrested two Canadians in China, Michael Kovrig and Michael Spavor, in apparent retribution. ${ }^{2}$ Immediately after Meng's return, China released the Canadians and also allowed two U.S. citizens, siblings Cynthia and Victor Liu, to return to the United States after preventing their departure with an exit ban since 2018. ${ }^{3}$ The incident has raised concerns about "hostage diplomacy," and questions remain about whether the case's resolution will help to stabilize or even improve tense relations between the United States and China. ${ }^{4}$

In a thirteen-count indictment issued in August 2018 and partially unsealed in January 2019, the United States charged Meng and Huawei with wire fraud and bank fraud,

opa/pr/eight-individuals-charged-conspiring-act-illegal-agents-people-s-republic-china [https://perma.cc/ XM3H-FZMT].

${ }^{37}$ See 18 U.S.C. $\$ 3181$ (listing U.S. bilateral extradition treaties in the Statutory Notes and showing no such treaties with China or Iran).

${ }^{1}$ David E. Sanger, Dan Bilefsky \& Katie Benner, U.S. Agrees to Release Huawei Executive in Case That Strained Ties with China, N.Y. Times (Sept. 24, 2021), at https://www.nytimes.com/2021/09/24/us/politics/huaweimeng-wanzhou.html.

${ }^{2}$ Chris Buckley \& Katie Benner, To Get Back Arrested Executive, China Uses a Hardball Tactic: Seizing Foreigners, N.Y. TIMES (Sept. 25, 2021), at https://www.nytimes.com/2021/09/25/world/asia/meng-wanzhouchina.html.

${ }^{3}$ Michael Forsythe, Chris Buckley \& Katie Benner, American Siblings Barred from Leaving China for 3 Years Return to U.S., N.Y. TimeS (Sept. 27, 2021), at https://www.nytimes.com/2021/09/27/us/politics/china-americans-released.html.

${ }^{4}$ See, e.g., Katie Benner \& David E. Sanger, How the Huawei Case Raised Fears of "Hostage Diplomacy" by China, N.Y. TIMES (Sept. 28, 2021), at https://www.nytimes.com/2021/09/28/us/politics/huawei-meng-wanzhou.html; Dan Bilefsky, Meng's Release Could Eliminate a Source of Friction Between China and the Biden Administration, N.Y. TimES (Sept. 24, 2021), at https://www.nytimes.com/2021/09/24/world/canada/meng-wanzhou-biden-china. html. 